\title{
Improving Environmental Care Characters Through E- Modules Based on Local Wisdom Mangrove Ecotourism
}

\section{Syahrial ${ }^{1}$, Asrial ${ }^{2}$, Dwi Agus Kurniawan ${ }^{3}$, Nurul Delima Kiska ${ }^{4}$}

1,2,3,4 Jambi University, Jambi, Indonesia

\section{ART I CLE I N F O}

Article history:

Received March 08, 2021

Revised March 11, 2021

Accepted April 30, 2021

Available online May 25, 2021

Kata Kunci:

Respon, E-Modul, Peduli

Lingkungan

Keywords

Response, E-Module,

Environmental Care

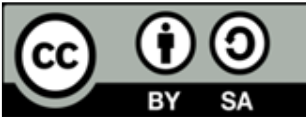

This is an open access article under the CC BY-SA license.

Copyright $(2021$ by Author. Published by Universitas Pendidikan Ganesha.

\begin{abstract}
A B S T R A K
Guru kurang mampu mengembangkan modul elektronik yang mampu meninkatkan karakter siswa. Modul elektronik seharusnya didesain dengan materi yang memanfaatkan lingkungan sekitar siswa agar kegiatan pembelajaran terkesan lebih nyata. Penelitian ini dilakukan bertujuan untuk menganalisis hubungan karakter peduli lingkungan yang di integrasikan dengan modul elektronik berbasis kearifan lokal ekowiasata mangrove. Jenis penelitian ini yaitu kuantitatif asosiatif. Sampel pada penelitian ini berjumlah 22 orang, dengan menggunakan teknik sampling adalah sampling purposive. Instrumen pengumpulan data yang digunakan adalah angket. Analisis data menggunakan statistik desktriptif kualitatif dan kuantitaif. Hasil pada penelitian ini adalah karakter peduli lingkungan yang dimiliki peserta didik memiliki katergori baik, dilihat dari indikator karakter peduli lingkungan setelah menggunakan modul elektronik berbasis kearifan lokal, diperkuat dengan hasil korelasi yang didapatkan sebesar 0,885 serta menghasilkan hubungan yang sangat baik, dimana dalam menggunakan modul elektronik memiliki kaitan yang erat dengan karakter peduli lingkungan. Maka dari itu sangat penting bagi penyelenggara pendidikan baik siswa maupun guru dalam pengimplementasian modul elektronik berbasisi kearifan lokal yang dapat dimanfaatkan dalam menanam karakter peduli lingkungan pada siswa.
\end{abstract}

\section{A B S T R A C T}

Teachers are less able to develop electronic modules that can improve student character. Electronic modules should be designed with materials that take advantage of the environment around students so that learning activities seem more real. This research was conducted to analyze the relationship between caring for the environment, integrated with an electronic module based on local wisdom of mangrove ecotourism. This type of research is quantitative associative. The sample in this study amounted to 22 people, using a sampling technique called purposive sampling. The data collection instrument used was a questionnaire. Data analysis used descriptive qualitative and quantitative statistics. The results in this study are that the environmental care character possessed by students has a good category, seen from the environmental care character indicator after using an electronic module based on local wisdom, strengthened by the correlation results obtained by 0.885 and produces a very good relationship, wherein using the electronic module has a close relationship with the character of caring for the environment. Therefore, both students and teachers need to implement electronic modules based on local wisdom that can be used to instil environmental care characters in students.

\section{INTRODUCTION}

A country will develop well with a community of character. Character education is a form of conscious effort to objectively realise student behaviour and attitudes to welcome the times (Komalasari \& Rahmat, 2019; Munawwaroh, 2019; Wuryani \& Yamtinah, 2018). The development of the times is often heard as globalization, which brings foreign cultures into the Indonesian people's social, cultural, economic, and educational situations. To welcome the times of globalization in the world of education that utilizes technology in learning activities (Chang et al., 2021; Goldschmidt, 2020; Sprenger \& Schwaninger, 2021). The development of the benefits of technology is widely used in various fields. The technology used in education can improve quality, provide more benefits, and cover limitations in learning activities 
(Chang et al., 2021; Chin \& Wang, 2021). Technology is essential in education, used as a management system and learning media that can support success in education. Technology in education positively impacts providing good quality (Liao et al., 2018; Yavuz et al., 2021). The problem that occurs today is that teachers cannot use technology in learning (MacLachlan et al., 2018; Muhtadi et al., 2018). The development of increasingly sophisticated technology is beneficial in the world of education. Teachers can use the help of technology to create interactive teaching materials for students. However, many teachers have not created attractive, interactive teaching materials for students (Kimianti \& Prasetyo, 2019; Muzijah et al., 2020). The findings of previous studies also state that teachers have not been able to develop electronic teaching materials (Raharjo et al., 2017; Rusli \& Antonius, 2019; Winatha et al., 2018).

Teaching materials can help teachers in facilitating learning activities. The application of electronic learning modules as teaching materials must be by the concepts and competencies to be achieved in learning activities that do not rely too much on the teacher in learning and are sure to be more effective in learning (Astra et al., 2020; Aufa et al., 2021; Logan et al., 2021). The electronic module as a learning tool can contain animations, sounds, videos, and films designed in the form of electronic books that are made to help achieve competence in learning (Elder et al., 2019; Hamdunah et al., 2016). Electronic modules are done systematically by utilizing the circumstances around students to learn independently (Neppala et al., 2018; Seruni et al., 2020). By providing convenience in learning activities, please use electronic modules as teaching materials. Electronic modules should be designed with materials that utilize the environment around students so that learning activities seem more real (Raihan et al., 2018; Rosala \& Budiman, 2020). The teacher's obstacle in designing this electronic module teaching material is creating an accurate impression of learning activities. One of the modules that teachers can use is an electronic module based on local wisdom. In an electronic module based on local wisdom, Mangrove ecotourism on environmental care characters can improve students' character who cares about the environment (Izzati et al., 2013; Riwanti \& Hidayati, 2019; Rosala \& Budiman, 2020). This electronic module raises the character of caring for the environment, a person's general awareness that must be developed (Pradini et al., 2019). To produce a more concrete learning quality, the teacher designs learning modules with the student's environmental conditions.

Electronic modules in their application have a positive impact. Judging from its usefulness, the electronic module gives the impression of an exciting tool and encourages students to master the material presented by the teacher (Riyadi et al., 2017; Ula \& Fadila, 2018). Electronic modules can make learning activities more effective and efficient and motivate students in learning (Imansari \& Sunaryantiningsih, 2017). Learning media that extensively utilize technological developments that have a positive impact on students in learning and daily life are electronic modules (Astra et al., 2020; Logan et al., 2021). The impact of electronic modules on students is very influential in learning activities that impact learning outcomes. There are many studies on electronic module teaching materials. The findings of previous studies stated that E-modules were effectively used in learning (Ningsih \& Mahyuddin, 2021; Sofyan et al., 2019). Other research findings also state that E-modules make learning easier for students (Astra et al., 2020; Neppala et al., 2018; Yulando et al., 2019). It can be concluded that the E-module can facilitate students in learning. The absence of a study on the application of electronic modules in learning activities on environmental care characters was carried out to see the relationship between students' environmental care character indicators and the use of electronic modules based on local wisdom of mangrove ecotourism using the Professional 3D page flip application. This study has a difference from other studies, namely, this study examines the relationship of electronic modules to the character of caring for the environment, while in other studies, researchers research development. The purpose of this study is to analyze students' environmental care character after applying an electronic module based on local wisdom of mangrove ecotourism.

\section{METHOD}

This research is an associative quantitative research using the correlation analysis technique. The associative method is used to discuss a relationship between two or more variables (Muniady et al., 2014). The researchers used associative research methods with correlational analysis to determine the relationship between the electronic module based on local wisdom of mangrove ecotourism with environmental care characters. A product-moment correlation is produced to produce research that is valid internally and can be changed externally, and assessing the relationship between the construction of data analysis techniques used in processing the data. Product moment correlation is a parametric statistical test tool used to test the relationship between two random, homogeneous, and normally distributed samples. Data processing is carried out with the help of the SPSS program. A population is a group that is larger in number and is usually used to generalize research results. The population in this 
study were all students of SD N 64/I Muara Bulian. The sample of this research is a set of elements that are sampled. However, other elements are also possible such as groups (teachers, schools, classes) or objects (teachers, textbooks, school notes, and television). The sampling technique used is purposive sampling, namely the technique of determining the sample with specific considerations (Kholidin et al., 2020). The sampling technique in this research is purposive sampling with the criteria that students are seen from their gender, students are seen from their activeness in class and students are seen from their ability to communicate well with teachers and peers.

In collecting data, the research instrument in this study used questionnaires and interviews. In this study, the questionnaire used is a questionnaire of the two indicators in students' character, namely caring for the environment where the indicator consists of protecting the surrounding environment and saving energy. In determining the reliability, which serves to measure from a research test to remain consistent with the subject and under the same conditions. In calculating the reliability using the Cronbach alpha formula. The first indicator, namely protecting the surrounding environment, obtained a Cronbach alpha value of 0.780 and while the second indicator, namely energy-saving, obtained a Cronbach alpha value of 0.72 . With each Cronbach alpha value $>0.7$, the instrument is reliable. To determine the appropriate character in students using Likert. Where on the Likert scale type, namely strongly agree (SS), agree (S), not sure (N), disagree (TS), and strongly disagree (STS). Each positive item in the instrument has a score of: $\mathrm{SS}=5, \mathrm{~S}=4, \mathrm{~N}=3, \mathrm{TS}=2$, and $\mathrm{STS}=1$. Scores are reversed for negative items. This questionnaire was filled out to obtain data to determine the effect of an electronic module based on mangrove ecotourism on the character of caring for the environment with two indicators, namely maintaining the surrounding environment and also saving energy which was carried out in class IV SD N 64/I Muara Bulian.

Module validation is carried out to determine the level of using electronic modules. The validation of this module is carried out by experts, namely linguists, material experts, media experts and expert practitioners. In conducting validation, the experts filled out the instrument made by the researcher in the form of a Likert scale with positive questions. The data obtained were analyzed using two stages, the first of which was to add up the total score of each expert for all indicators, and the second stage was to provide a validation score by adding up all the scores obtained divided by the maximum score and then multiplied by 100\%. Data were obtained using data collection procedures. Electronic modules are assessed by linguists, materials experts, media experts and expert practitioners. Experts fill out a questionnaire to see progress. The grid of the questionnaire is presented in table 2,3,4.

Table 1. Validation of the modified Likert scale electronic module

\begin{tabular}{cc}
\hline Percentage (\%) & Criteria \\
\hline $0-20$ & Not feasible \\
$21-40$ & Not worth it \\
$41-60$ & Decent enough \\
$61-80$ & worthy \\
$81-100$ & Very worth it \\
\hline
\end{tabular}

Table 2. Grid of Module validation sheets for material experts

\begin{tabular}{cc}
\hline Criteria & Indicator \\
\hline Content eligibility & The suitability of the material with KD \\
Material accuracy \\
Curiosity Advancement \\
Find and explain strategies in solving problems \\
Expressing ideas verbally or in writing \\
Evaluating arguments \\
Solve a problem in various ways \\
Teknik penyajian \\
Pendukung Penyajian \\
Penyajian Pembelajaran \\
Language Eligibility \\
Koherensi dan Keruntutan Alur Berpikir \\
Lugas \\
Komunikatif, Dialogis dan Interaktif \\
Kesesuaian dengan Kaidah Bahasa \\
Penggunaan notasi, Simbol/Lambang
\end{tabular}


Table 3. Grid validation sheet Module for media experts

\begin{tabular}{cc}
\hline Criteria & Indicator \\
\hline Graphics Eligibility & Module Size \\
& Module Cover Design \\
& Module Content Design \\
Electronic Media & Software engineering \\
Eligibility & Visual Communication \\
& Audio Communication \\
\hline
\end{tabular}

Table 4. Grid validation sheet Module for linguists

\begin{tabular}{ll}
\hline Criteria & Indicator \\
\hline Eligibility of the language used in the & Correct sentence structure \\
module & Sentence effectiveness \\
& Term standard \\
& Understanding of messages or information \\
& Ability to motivate students \\
& Conformity to the intellectual development of students \\
& Conformity to the level of students' emotional development \\
& Grammatical accuracy \\
& Spelling accuracy \\
\hline
\end{tabular}

Data analysis in this study used descriptive and inferential statistics. Descriptive statistics are used to determine each variable's maximum, minimum, average, and standard deviation values by describing or describing (Triangle, 2015). Descriptive statistics are used to provide an overview of the data and empirical data that have been collected (Ningsih et al., 2017). In this study, the data analysis method used is maximum, minimum, and average or mean.

\section{RESULT AND DISCUSSION}

\section{Result}

Grade IV B students enthusiastically welcomed the implementation of this electronic module at SD N 64/I Muara Bulian. Teachers and students responded very positively in learning activities using electronic modules based on local mangrove wisdom. Students are very enthusiastic when learning, and the curiosity of students increases. Descriptive data analysis of the effect of electronic modules based on local wisdom of mangrove ecotourism on improving students' character who care about the environment processed with the SPSS 20 application. 1 of 22 students), students in the bad category were $9.09 \%$ (2 out of 22 students) students with sufficient category were $9.09 \%$ (2 out of 22 students), students with good categories were $31.81 \%$ (7 of 22 students). 22 students), and students with very good attitudes were $45.45 \%$ ( 10 out of 22 students). Based on the attitude scale from the results of the data above, it shows that the data obtained is a mean value of 70.95 , a maximum of 81 , and a minimum of 62 . These results indicate that students' attitudes towards environmental care indicators on the indicator of protecting the environment show a positive attitude seen from the results of data analysis. $16.68 \%$ of students or from a total of 22 students in the excellent category. It is also supported by the mean result of 70.95 , which is a good category.

Based on the results of the analysis of the results of environmental care characters on energysaving indicators, the students' character categories are very bad as much as $4.45 \%$ ( 1 of 22 students), students with wrong categories are $4.45 \%$ ( 1 of 22 students) students with moderate categories as many as $9.09 \%$ ( 2 of 22 students), students with good category as many as $31.81 \%$ (7 of 22 students), and students with very good attitude as many as $50 \%$ (11 of 22 students). Based on the attitude scale from the data results above, it shows that the data obtained is a mean value of 80.63 , a maximum of 81 , and a minimum of 62 .

Table 5. Student Responses to Electronic Modules

\begin{tabular}{ccccccc}
\hline Interval & Catagory Attitude & Total & Mean & Min & Max & \% \\
\hline $69-74$ & Very Not Good & 0 & & & & 0 \\
$75-79$ & Not good & 2 & & & & 9 \\
$80-84$ & Enough & 2 & 87,0 & 69 & 96 & 9 \\
\hline
\end{tabular}




\begin{tabular}{ccccccc}
\hline Interval & Catagory Attitude & Total & Mean & Min & Max & $\mathbf{\%}$ \\
\hline $85-90$ & Well & 10 & & & & 45 \\
$91-96$ & Very good & 8 & & & & 37 \\
\hline TOTAL & & $\mathbf{2 2}$ & & & & $\mathbf{1 0 0}$ \\
\hline
\end{tabular}

Based on the questionnaire from students' responses to the electronic module to see the character of students, the results obtained in several categories, namely very bad students, none, $9 \%$ students with bad categories ( 2 out of 22 students), 9\% students with sufficient categories (2 out of 22 students), in the good category there are $45 \%$ (10 of 22 students). On the attitude scale, the data above shows that the data obtained is a mean value of 87.0 , a minimum of 69 , and a maximum of 96 . These results indicate that the attitude of students' responses to the electronic module shows a positive attitude as seen from the results of data analysis that $45 \%$ of students or 10 of a total of 22 students in the good category. The normality and linearity assumption test results from the response questionnaire data on the students' environmental care characters were processed using SPSS version 20.0, namely the normality value of 0.228 at the sig normality value, meaning that the existing data is expected the sig value> 0.05 . The Kolmogorov Smirnov-based normality test results from two independent samples yielded a significance value of $0.997>0.05$. Thus the residual value was normally distributed. The results of the linearity test of the sig deviation from linearity value of $0.664>0.05$, it can be concluded that there is a linear relationship between the Electronic Module and the Environmental Care Officer. The correlation result is 0.885 , and the sig value is 0.000 , which is smaller than 0.05 . It can be concluded that there is a relationship between the response of the electronic module based on the local wisdom of mangrove ecotourism to the character of students who care about the environment. Based on the results of data analysis of the relationship between the response and the electronic module based on local wisdom of mangrove ecotourism, the correlation between the response and the electronic module is 0.937 . The second relationship is strong, by obtaining a signed value of $0.000<0.005$ so it can be concluded that there is a relationship between the response and the electronic module with an R-value of 0.937, and it can be said that there is a mutual relationship between the response and the electronic module.

\section{Disccusion}

Based on the results of data analysis, the developed electronic module can be applied in learning as teaching materials and can improve the character of caring for the environment. This is because the value of local wisdom in the electronic module discusses natural ecotourism, namely mangroves. The data results show that the student's character shows a positive effect on the influence of environmental care characters with indicators of protecting the surrounding environment, which is of good value in the results of data analysis. Regarding the character of caring for the environment by protecting the surrounding environment, which is the first indicator, it is strengthened by the results of interviews, which conclude that students have the character of caring for the environment. Caring for the environment is an attitude and action that seeks to prevent damage to the surrounding natural environment (Carling, 2021; Franklin et al., 2021). In the attitude of protecting the surrounding environment, there is still a lack of awareness owned by each individual, therefore the importance of inculcating from the age of elementary school students regarding the attitude of protecting the surrounding environment. The character of students on the indicator of the influence of the electronic module based on local wisdom of mangrove ecotourism to improve the character of students who care about the environment, which shows a positive thing about the influence of the character of caring for the environment with indicators of protecting the surrounding environment, which is of good value in the results of data analysis. This is also supported by the results of interviews conducted showing the effect of electronic modules based on local wisdom of mangrove ecotourism to improve students' character in the excellent category. One of the positive impacts of applying the influence of electronic modules is that students are motivated to learn (Dumitrescu et al., 2014; Resita \& Ertikanto, 2018; Sadimin Sadimin et al., 2017). Learning activities in safe and comfortable classroom management can make students more focused on participating in learning activities (Mastroleo et al., 2020; Puspoko Jati et al., 2019).

These results show students' attitudes towards energy saving indicators. This shows a positive attitude, seen from the results of data analysis that 80.63 students or a total of 22 students are in the very good category. This is also supported by the mean result of 80.63 which is a good category. These results are also reinforced by the results of interviews to determine the attitudes that indicate energy saving by students. Therefore, character education is very important to change the way of thinking, behaving, and the way a person cares about the surrounding environment (Cervera-Gasch et al., 2021; Hattingh \& Downing, 2020). Thus the electronic module can have an influence on students in shaping students'character (Istuningsih et al., 2018; Kiong et al., 2012; Majid et al., 2012). This research has a 
novelty in a study where the renewability is found in the variables studied, namely the character of caring for the environment which is taken by two indicators, namely protecting the surrounding environment and also saving energy which is to determine the relationship between these indicators, researchers with the application of electronic modules in this study. The limitations in this study are in the learning competencies, namely class VI with theme 3 "Care for Living Creatures" and Subtheme 3 ", Let's Love the Environment" in learning 1, which is based on Local Wisdom for Mangrove Ecotourism in Pangkal Babu using the Kivsoft Flipbook Maker application which is applied to the character. Environmental care, social care, and responsibility. This research implies that teaching materials in the form of electronic modules can be used to feel natural and learn with an independent system. Recommendations from researchers are in learning activities delivered by teachers to be developed or varied by utilizing the times, namely in the form of technology, information and communication, in order to increase students' motivation to learn and improve student character, especially the character of students who care about the environment.

\section{CONCLUSION}

The environmental care character possessed by the students has a suitable category, seen from the environmental care character indicator after using an electronic module based on local wisdom. It can be concluded that the electronic module based on the local wisdom of Mangrove ecotourism can shape the character of environmental care in students. Therefore, both students and teachers need to implement electronic modules based on local wisdom that can be used to instil environmental care characters in students.

\section{REFERENCES}

Astra, I. M., Raihanati, R., \& Mujayanah, N. (2020). Development of Electronic Module Using Creative Problem-Solving Model Equipped with Hots Problems on The Kinetic Theory of Gases Material. Jurnal Penelitian \& Pengembangan Pendidikan Fisika, 6(2), 181-194. https: //doi.org/10.21009/1.06205.

Asyhar, R. (2012). Kreatif Mengembangkan Media Pembelajaran. Refrensi Jakarta.

Aufa, M. N., Rusmansyah, R., Hasbie, M., Jaidie, A., \& Yunita, A. (2021). The Effect of Using e-module Model Problem Based Learning (PBL) Based on Wetland Environment on Critical Thinking Skills and Environmental Care Attitudes. Jurnal Penelitian Pendidikan IPA, 7(3), 401-407. https://doi.org/10.29303/jppipa.v7i3.732.

Carling, P. C. (2021). Health Care Environmental Hygiene: New Insights and Centers for Disease Control and Prevention Guidance. Infectious Disease Clinics of North America, 35(3). https: //doi.org/10.1016/j.idc.2021.04.005.

Cervera-Gasch, A., González-Chordá, V. M., Ortiz-Mallasen, V., Andreu-Pejo, L., \& Mena-Tudela, D. (2021). Student satisfaction level, clinical learning environment, and tutor participation in primary care clinical placements: An observational study. Nurse Education Today, 1. https: //doi.org/10.1016/j.nedt.2021.105156.

Chang, H.-Y., Wu, H.-F., Chang, Y.-C., Tseng, Y.-S., \& Wang, Y.-C. (2021). The effects of a virtual simulationbased, mobile technology application on nursing students' learning achievement and cognitive load: Randomized controlled trial. International Journal of Nursing Studies, 120. https: //doi.org/10.1016/j.ijnurstu.2021.103948.

Chin, K.-Y., \& Wang, C.-S. (2021). Effects of augmented reality technology in a mobile touring system on university students' learning performance and interest. Australasian Journal of Educational Technology, 37(1). https://doi.org/10.14742/ajet.5841.

Dumitrescu, C., Olteanu, R. L., Gorghiu, L. M., \& Gorghiu, G. (2014). Learning Chemistry in the Frame of Integrated Science Modules - Romanian Student's Perception. Procedia - Social and Behavioral Sciences, 116(September 2015), 2516-2520. https://doi.org/10.1016/j.sbspro.2014.01.603.

Elder, J. J., Franco, K. A., Gulley, S. L., Hughes, C. T., \& Infanti, L. M. (2019). Implementation of Required Electronic Learning Modules to Enhance Nursing Pharmacotherapy Knowledge of Select Hematopoietic Stem Cell Transplant Topics. Biology of Blood and Marrow Transplantation, 25(3), S303. https://doi.org/10.1016/j.bbmt.2018.12.655.

Franklin, A., Udall, D., Schmutz, U., \& Rayns, F. (2021). 'Hell or high water': Good farming and environmental care as contested practices in the implementation of nitrate vulnerable zones in Wales. Journal of Rural Studies, 83. https://doi.org/10.1016/j.jrurstud.2021.02.012.

Goldschmidt, K. (2020). The COVID-19 Pandemic: Technology use to Support the Wellbeing of Children. Journal of Pediatric Nursing, 53, 88-90. https://doi.org/10.1016/j.pedn.2020.04.013. 
Hamdunah, Yunita, A., Zulkardi, \& Muhafzan. (2016). Development a Constructivist Module and Web on Circle and Sphere Material with Wingeom Software. Journal on Mathematics Education, 7(2), 109116. https://doi.org/10.22342/jme.7.2.3536.109-116.

Hattingh, H., \& Downing, C. (2020). Clinical learning environment: Lived experiences of post-basic critical care nursing students. International Journal of Africa Nursing Sciences, 13. https://doi.org/10.1016/j.ijans.2020.100263.

Imansari, N., \& Sunaryantiningsih, I. (2017). Pengaruh Penggunaan E-Modul Interaktif Terhadap Hasil Belajar Mahasiswa Pada Materi Kesehatan dan Keselamatan Kerja. VOLT: Jurnal Ilmiah Pendidikan Teknik Elektro, 2(1), 11-16. https://doi.org/10.30870/volt.v2i1.1478.

Istuningsih, W., Baedhowi, B., \& Sangka, K. B. (2018). The effectiveness of scientific approach using emodule based on learning cycle 7e to improve students' learning outcome. International Journal of Educational Research Review, 3(3). https://doi.org/10.24331/ijere.449313.

Izzati, N., Hindarto, N., \& Pamelasari, S. D. (2013). Pengembangan modul tematik dan inovatif berkarakter pada tema pencemaran lingkungan untuk siswa kelas VII SMP. Jurnal Pendidikan IPA Indonesia, 2. https://doi.org/10.15294/jpii.v2i2.2721.

Kholidin, F. I., Rachmawati, I., \& Laksana, E. P. (2020). Kontribusi kepercayaan diri dan efikasi diri akademik terhadap nilai mata kuliah statistik inferensial. Ejournal Ressi.Id, 2(2), 46-54. https://doi.org/10.33292/ter.v2i2.68.

Kimianti, F., \& Prasetyo, Z. K. (2019). Pengembangan E-Modul Ipa Berbasis Problem Based Learning Untuk Meningkatkan Literasi Sains Siswa. Kwangsan: Jurnal Teknologi Pendidikan, 7(2), 91. https://doi.org/10.31800/jtp.kw.v7n2.p91--103.

Kiong, T. T., Yunos, J. M., Mohammad, B., Othman, W., Heong, Y. M., \& Mohamad, M. M. (2012). The Development and Implementation of Buzan Mind Mapping Module. Procedia - Social and Behavioral Sciences, 64. https://doi.org/10.1016/j.sbspro.2012.11.464.

Komalasari, K., \& Rahmat, R. (2019). Living Values Based Interactive Multimedia in Civic Education Learning. International Journal of Instruction, 12(1), 113-126. https://doi.org/10.29333/iji.2019.1218a.

Liao, S., Hong, J.-C., Wen, M.-H., Pan, Y.-C., \& Wu, Y.-. (2018). Applying Technology Acceptance Model (TAM) to explore Users' Behavioral Intention to Adopt a Performance Assessment System for E-book Production. EURASIA Journal of Mathematics, Science and Technology Education, 14(10). https: //doi.org/10.29333/ejmste/93575.

Logan, R. M., Johnson, C. E., \& Worsham, J. W. (2021). Development of an E-learning Module to Facilitate Student Learning and Outcomes. Teaching and Learning in Nursing, 16(2), 139-142. https: //doi.org/10.1016/j.teln.2020.10.007.

MacLachlan, M., Banes, D., Bell, D., Borg, J., Donnelly, B., Fembek, M., Ghosh, R., Gowran, R. J., Hannay, E., Hiscock, D., Hoogerwerf, E. J., Howe, T., Kohler, F., Layton, N., Long, S., Mannan, H., Mji, G., Odera Ongolo, T., Perry, K., ... Hooks, H. (2018). Assistive technology policy: a position paper from the first global research, innovation, and education on assistive technology (GREAT) summit. Disability and Rehabilitation: Assistive Technology, 13(5), 454-466. https: //doi.org/10.1080/17483107.2018.1468496.

Majid, M. S. Z. B. A., Ali, M. M. B. A., Rahim, A. A. B. A., \& Khamis, N. Y. B. (2012). The Development of Technical English Multimedia Interactive Module to Enhance Student Centered Learning (SCL). Procedia - Social and Behavioral Sciences, 67, 345-348. https: //doi.org/10.1016/j.sbspro.2012.11.337.

Mastroleo, N. R., Humm, L., Williams, C. M., \& Kiluk, B. D. (2020). Initial testing of a computer-based simulation training module to support clinicians' acquisition of CBT skills for substance use disorder treatment. Journal of Substance Abuse Treatment, 114. https://doi.org/10.1016/j.jsat.2020.108014.

Muhtadi, D., Wahyudin, Kartasasmita, B. G., \& Prahmana, R. C. I. (2018). The Integration of technology in teaching mathematics. Journal of Physics: Conference Series, 943(1), 1-9. https://doi.org/10.1088/1742-6596/943/1/012020.

Munawwaroh, A. (2019). Keteladanan Sebagai Metode Pendidikan Karakter. Jurnal Penelitian Pendidikan Islam, 7(2), 141. https://doi.org/10.36667/jppi.v7i2.363.

Muniady, R., Al-Mamun, A., Yukthamarani Permarupan, P., \& Binti Zainol, N. R. (2014). Factors influencing consumer behavior: A study among university students in Malaysia. Asian Social Science, 10(9), 18-25. https://doi.org/10.5539/ass.v10n9p18.

Muzijah, R., Wati, M., \& Mahtari, S. (2020). Pengembangan E-modul Menggunakan Aplikasi Exe-Learning untuk Melatih Literasi Sains. Jurnal Ilmiah Pendidikan Fisika, 4(2), 89. https: //doi.org/10.20527/jipf.v4i2.2056. 
Neppala, P., Sherer, M. V., Larson, G., Bryant, A. K., Panjwani, N., Murphy, J. D., \& Gillespie, E. F. (2018). An interactive contouring module improves engagement and interest in radiation oncology among preclinical medical students: Results of a randomized trial. Practical Radiation Oncology, 8(4). https://doi.org/10.1016/j.prro.2018.01.001.

Ningsih, Misdalina, \& Marhamah. (2017). Peningkatan Hasil Belajar dan Kemandirian Belajar Metode Statistika Melalui Pembelajaran Blended Learning. Al-Jabar: Jurnal Pendidikan Matematika, 8(2), 155-164. https://doi.org/10.24042/ajpm.v8i2.1633.

Ningsih, S. Y., \& Mahyuddin, N. (2021). Desain E-Module Tematik Berbasis Kesantunan Berbahasa Anak Usia Dini di Taman Kanak-Kanak. Jurnal Obsesi : Jurnal Pendidikan Anak Usia Dini, 6(1), 137-149. https://doi.org/10.31004/obsesi.v6i1.1217.

Pradini, I. K., Sudjanto, B., \& Nurjannah, N. (2019). Implementasi program sekolah adiwiyata dalam peningkatan mutu pendidikan di SDN Tanah Tinggi 3 Kota Tangerang. Jurnal Green Growth Dan Manajemen Lingkungan, 7(2), http://journal.unj.ac.id/unj/index.php/jgg/article/view/7811.

Puspoko Jati, D. H., Ismanto, B., \& Sulasmono, B. S. (2019). The Development of Local Wisdom Based Character Education Training Module. Journal of Education Research and Evaluation, 3(1), 1-9. https: //doi.org/10.23887/jere.v3i1.17763.

Raharjo, M. W. C., Suryati, S., \& Khery, Y. (2017). Pengembangan E-Modul Interaktif Menggunakan Adobe Flash Pada Materi Ikatan Kimia Untuk Mendorong Literasi Sains Siswa. Hydrogen: Jurnal Kependidikan Kimia, 5(1), 8. https://doi.org/10.33394/hjkk.v5i1.102.

Raihan, S., Haryono, \& Ahmadi, F. (2018). Development of Scientific Learning E-Book Using 3D Pageflip Professional Program. Innovative Journal Of Curriculum and Educational Technology, 7(1), 7-14.

Resita, I., \& Ertikanto, C. (2018). Designing electronic module based on learning content development system in fostering students' multi representation skills. Journal of Physics: Conference Series, 1022(1), 012025. https://doi.org/10.1088/1742-6596/1022/1/012025.

Riwanti, R., \& Hidayati, A. (2019). Pengembangan Modul Pembelajaran Tematik Berbasis Pendidikan Karakter Di Kelas V Sekolah Dasar. Jurnal Basicedu, 3(2), 572-581. https://doi.org/10.31004/basicedu.v3i2.41.

Riyadi, S., Qamar, K., \& Universitas Kanjuruhan Malang, Jawa Timur, I. (2017). Efektivitas E-Modul Analisis Real Pada Program Studi Pendidikan Matematika Universitas Kanjuruhan Malang. Supremum Journal of Mathematics Education (SJME) Journal, 1(1), 26-33.

Rosala, D., \& Budiman, A. (2020). Local Wisdom-based Dance Learning: Teaching Characters to Children through Movements. Mimbar Sekolah Dasar, 7(3), 304-326. https://doi.org/10.17509/mimbarsd.v7i3.28185.

Rusli, M., \& Antonius, L. (2019). Meningkatkan Kognitif Siswa SMAN I Jambi Melalui Modul Berbasis EBook Kvisoft Flipbook Maker. Jurnal Sistem Komputer Dan Informatika (JSON), 1(1), 59. https://doi.org/10.30865/json.v1i1.1397.

Sadimin Sadimin, Wahyu Hardyanto, \& Slamet, A. (2017). Developing An E-Module-Based Classroom Action Research Management Training Model For Teachers High School. International Journal of Education and Research, 5(2), 79-90. https://doi.org/10.15294/jed.v5i3.18123.

Seruni, R., Munawaroh, S., Kurniadewi, F., \& Nurjayadi, M. (2020). Implementation of e-module flip PDF professional to improve students' critical thinking skills through problem based learning. Journal of Physics: Conference Series, 1521(4), 1-6. https://doi.org/10.1088/1742-6596/1521/4/042085.

Sofyan, H., Anggereini, E., \& Saadiah, J. (2019). Development of E-Modules Based on Local Wisdom in Central Learning Model at Kindergartens in Jambi City. European Journal of Educational Research, 8(4), 1137-1143. https://doi.org/10.12973/eu-jer.8.4.1137.

Sprenger, D. A., \& Schwaninger, A. (2021). Technology acceptance of four digital learning technologies (classroom response system, classroom chat, e-lectures, and mobile virtual reality) after three months' usage. International Journal of Educational Technology in Higher Education, 18(1), 1-17. https://doi.org/10.1186/s41239-021-00243-4.

Triangle, P. F. (2015). Analisis Determinan Financial Statement Melalui Pendekatan Fraud Triangle. Accounting Analysis Journal, 4(1), 1-10. https://doi.org/10.15294/aaj.v4i1.7761.

Ula, I. R., \& Fadila, A. (2018). Pengembangan E-Modul Berbasis Learning Content Development System Pokok Bahasan Pola Bilangan SMP. Desimal: Jurnal Matematika, 1(2), 201. https://doi.org/10.24042/djm.v1i2.2563.

Winatha, K. R., Naswan, S., \& Ketut, A. (2018). Pengembangan E-modul Interaktif Berbasis Proyek Pada Mata Pelajaran Simulasi Digital Kelas X di SMK TI Bali Global Singaraja. Jurnal Teknologi Pembelajaran Indonesia, 8(1). https: //doi.org/10.23887/jtpi.v8i1.2238.

Wuryani, M. T., \& Yamtinah, S. (2018). Textbooks Thematic Based Character Education on Thematic 
Learning Primary School: An Influence. International Journal of Educational Methodology, 4(2), 75-81. https://doi.org/10.12973/ijem.4.2.75.

Yavuz, M., Çorbacıoğlu, E., Başoğlu, A. N., Daim, T. U., \& Shaygan, A. (2021). Augmented reality technology adoption: Case of a mobile application in Turkey. Technology in Society, 66. https://doi.org/10.1016/j.techsoc.2021.101598.

Yulando, S., Sutopo, S., \& Franklin Chi, T. (2019). Electronic Module Design and Development: An Interactive Learning. American Journal of Educational Research, 7(10), 694-698. https: //doi.org/10.12691/education-7-10-4. 